DOI: $10.20472 / T E .2017 .5 .2 .003$

\title{
ARE FEMALES BETTER LANGUAGE LEARNERS-FROM AN ASPECT OF MULTIPLE INTELLIGENCES AND AMBIGUITY TOLERANCE
}

\author{
YEN-JU HOU, YI-AN HOU
}

\begin{abstract}
:
The study aimed to investigate, from an aspect of multiple intelligences (MI) and second language tolerance of ambiguity (SLTA), to see why females are always regarded as better language learners. Subjects were 284 college students in Taiwan, including 81 males and 203 females. The research instruments were surveys of Multiple Intelligences (MI) (Gardner, 1983) and Second Language Tolerance of Ambiguity Scale (SLTAS) (Ely, 1995). In addition, students' English levels of Taiwan College Entrance Exam were used as their English proficiency. All available data were analyzed using descriptive and inferential statistics derived from SPSS 17 . The results of the study revealed that females were really supported to be better language learners. Some implications derived from the findings were provided for more effective language teaching and learning.
\end{abstract}

\section{Keywords:}

gender difference, multiple intelligences, tolerance of ambiguity, English proficiency

JEL Classification: 129

\section{Authors:}

YEN-JU HOU, Shu Zen Junior College of Medicine and Management, Taiwan, Email: hycheng@mail.knu.edu.tw YI-AN HOU, St.Mary's Junior College of Medicine, Nursing and Management, Taiwan, Email: hycheng@mail.knu.edu.tw

\section{Citation:}

YEN-JU HOU, YI-AN HOU (2017). Are females better language learners-From an aspect of Multiple Intelligences and ambiguity tolerance. International Journal of Teaching and Education, Vol. V(2), pp. 32-56., 10.20472/TE.2017.5.2.003 


\section{Introduction}

Introduction included (1) background of the study, (2) purpose of the study, and (3) limitation of the study. They were described below:

\subsection{Background of the study}

Any research investigating second/foreign learning can't avoid being dependent on the question: "Who learns what languages where" (Dornyei, 1994, p.275). That is to say the learner, the target language, and the learning situation are the three major concerns of the study of second/ foreign language. Especially, there has been an increasing interest in changing the focus from the language learning product to the language learning processes, and the factors dealing with language learners have attracted much more attention than ever before. Such factors include "unchangeable" ones (such as age, gender, aptitude, and first language), and some other "predispositions" (motivation, attitude, tolerance of ambiguity, anxiety, field dependence/ independence, cognitive styles, and learning strategies) (Jamieson, 1992). Although the interest exhibited by psychologists can be dated back to Frenkel-Brunswik's study (1949), among those "predispositions", tolerance of ambiguity seems to have been least investigated until Ely's 12-item Second Language Tolerance of Ambiguity Scale (SLTMS) was developed in the early 20th. However, it also lacks the consensus for being classified as a variable of cognitive, personality, or both. For example, Frenkel-Brunswik (1949), Budner (1962), and Naiman, et al. (1975) conducted it as personality; Brown (1980) defined it as cognitive; Ely (1989) preferred both personality and cognitive; Chapelle and Roberts (1986) even exclaimed that tolerance of ambiguity, as well as Field Independence, "should be considered components of aptitude" (p.43). In addition, its effects on second/foreign language learning and on other variables related to language success are inconsistent and contradictory. Nevertheless, second/ foreign language learning is "a multi-faceted task" (Chapelle \& Roberts, 1986, p.44) which occurs in an ambiguous situation, and "fraught with uncertainty" (Ely, 1989, p.437), how learners "tolerate" such "ambiguity" to achieve success should be one of the major concerns in the light of language teaching and learning. Most importantly, what with Ely's English version of Second Language Tolerance of Ambiguity Scale (1995), and what with English has become the "Lingua Franca", studies of the effect of tolerance of ambiguity, together with other variables, on English teaching and learning has attracted much interest worldwide.

As for intelligence, it is "the ability to solve problems or fashion products that are valued in one or more cultural settings," defined by Gardner (1993, p.87). Gardner believed that we all have different combinations of intelligences which work together and make individuals different. But Gardner mentioned that our schools and culture focus most attention on linguistic and logical-mathematical intelligences and ignore other intelligences. He claimed that we should also place equal attention on those who show gifts in the other intelligences to enrich the world we live. So, Gardner created his theory of Multiple Intelligences (MI) in 1983. It's been proved that MI theory is very important to educators because it helps us expand our horizon of available teaching/learning tools beyond the conventional linguistic and logical methods by nurturing intelligences in many different potential pathways for an individualized learning environment. Though Gardner, the father 
of $\mathrm{MI}$, said he was less persuaded that it can be useful in mastering a foreign language, yet many teachers claim success using MI approaches.

Hence, the present study would like to see how the theory of MI goes in a Taiwan setting where English is learned as a foreign language, in particular, under gender differences, how students with different intelligences present their tolerance of ambiguity $(E l y, 1995)$ when learning a foreign language.

\subsection{Purpose of the study}

The study was an attempt to investigate, from an aspect of multiple intelligence (MI) and foreign language tolerance of ambiguity (SLTA) to see why females are always regarded as better language learners.

\subsection{Limitations of the study}

There were three limitations of the study. First, the sample size did not have a good balance of males and females (81:203), which may influence the results of gender differences. Second, as mentioned in the procedure, about $14.4 \%$ of the subjects didn't want to write their names on the answer sheets, which caused no way to find their English levels from files, and the sample size of the analysis of investigating some related factors was varied. Last, students might not be serious enough to fill out the questionnaire, which might influence the result to some extent.

\section{Related Literature}

Related literature included multiple intelligences (MI) and tolerance of ambiguity (AT). They were described below:

\subsection{Multiple intelligences}

Intelligence is "the ability to solve problems or fashion products that are valued in one or more cultural settings," defined by Gardner (1993, p.87). Gardner believed that we all have different combinations of intelligences which work together and make individuals different. But Gardner mentioned that our schools and culture focus most attention on linguistic and logical/ mathematical intelligences and ignore other intelligences. He claimed that we should also place equal attention on those who show gifts in the other intelligences to enrich the world we live. So, Gardner created his theory of Multiple Intelligences (MI) in 1983. It's known that Gardner had first listed the seven intelligences which met his criteria for intelligences, they were Linguistic/Verbal intelligence, Logical-Mathematical intelligence, Visual/Spatial intelligence, Musical/Rhythmic intelligence, Bodily-Kinesthetic intelligence, Interpersonal intelligence, and Intrapersonal intelligence. Later, he added the eighth intelligence (Naturalist intelligence), and worked for a possible ninth intelligence (Existential intelligence) (Gardner, 2003). It's been proved that $\mathrm{Ml}$ theory is very important to educators because it helps us expand our horizon of available teaching/learning tools beyond the conventional linguistic and logical methods by 
nurturing intelligences in many different potential pathways for an individualized learning environment. Though the study of how MI theory has implemented around the world, in the $25^{\text {th }}$ anniversary of the publication of "Frames of Mind: The Theory of Multiple Intelligences (2008), Gardner, the father of MI, wrote about "some various myths and misunderstanding of $\mathrm{Ml}$ theory- for example, confusing an intelligence with a learning style...."(http://www.old-pz.gse.harvard.edu/PIs/Mlat25.pdf).

The Multiple Intelligence (MI) theory offers teachers a way to examine and adopt the best teaching techniques and strategies in light of student's individual differences. It also encourages educators to view learners as equals regardless of quotient produced from a traditional intelligence exam. Teachers are aware of the fact that every classroom is full of students with different areas of interest, different ways of expressing themselves, different strengths and weakness and recognize that an effective teaching and learning is to help students appreciate their strengths and improve their weakness. Without doubt that Gardner deserves everyone's gratitude, in particular, language teachers appreciate how well the theory is applied in the language-learning process. With the help of the theory, language teachers can create activities flexible, reflective, logical, and creative for diverse students' individual differences (Christison, 1998). Christison (1996a) and Mckenzie (2004) described clearly how Gardner conceived these intelligences (p.11):

Logical/Mathematical Intelligence-the ability to use numbers effectively and reason well. Sample skills are understanding the basic properties of numbers, the principles of cause and effect, and the ability to predict.

Verbal/Linguistic Intelligence-the ability to use words effectively, both orally and in writing. Sample skills are remembering information, convincing others to help, and talking about language itself.

Visual/Spatial Intelligence-the ability to sense form, space, color, line, and shape. Sample skills include the ability to represent visual or spatial ideas graphically.

Bodily/Kinesthetic Intelligence-the ability to use the body to express ideas and feelings, and to solve problems. Sample skills are coordination, flexibility, speed, and balance.

Musical/Rhythmic Intelligence-the ability to sense rhythm, pitch, and melody. Sample skills are recognizing simple songs and being able to vary speed, tempo, and rhythm in simple melodies.

Interpersonal Intelligence-the ability to understand another person's moods, feelings, motivations, and intentions. Sample skills are responding effectively to other people, problem solving, and resolving conflict.

Intrapersonal Intelligence-the ability to understand yourself, your strengths, weakness, moods, desires, and intentions. Sample skills are understanding how one is similar to or different from others, reminding oneself to do something, knowing about oneself as a language learner, and knowing how to handle ones' feelings. 
Naturalist Intelligence-the ability to recognize species of plants or animals in one's environment.

Existential Intelligence-the ability to see the "big picture": "Why are we here?" "What is my role in the world?"

\subsection{Tolerance of Ambiguity}

Tolerance of ambiguity is a person's ability to function properly in a situation where the interpretation of the stimuli is unclear. Budner (1962) defined it as "the tendency to perceive ambiguous situations as desirable" (p.29). In addition, Ehrman (1994, 1999) pointed out that there were three levels of function for tolerance of ambiguity, including intake, tolerance of ambiguity proper, and accommodation. During the three levels, when facing ambiguity or uncertainty situation, learners would be letting it in, accepting contradictions and incomplete information, and making distinctions, setting priorities, and restructuring cognitive schemata. As for intolerance of ambiguity, it was defined as "the tendency to perceive (i.e. interpret) ambiguous situations as sources of threat" (Budner, 1962, p.29), or "a tendency to perceive or interpret information marked by vague, incomplete ... or unclear meanings as actual or potential sources of psychological discomfort or threat" (Norton, 1975, p.608). Hence, tolerance of ambiguity can be seen as a person's characteristics to functionally perceive information in ambiguous situations or to become sources of psychological discomfort or threat. People with little tolerance of ambiguity are believed to experience more discomfort (Ely, 1995) and anxiety (Chapelle, 1983); to make guess early or agree with popular misconceptions (Levitt, 1953). They prefer memory or strategies which involve focusing on individual language elements (Ely, 1989), are more rigid (MacDonald,1970) and less inclined to take risks (Ely, 1995). They are easy to resort to black-and-white solutions (Frenkel-Brunswik,1949), have the tendencies to avoid ambiguous situations (Chapelle \& Roberts, 1986), or even drop the subject (Naiman, et al,1975). On the contrary, people with more tolerance of ambiguity appreciate being in ambiguous situations. They are willing to take risks, and are more receptive to change (McLain, 1993). By using more facility strategies, they can function better, gain more and excel in performance. It seems that people with more tolerance of ambiguity tend to have the advantage to become good language learners, while those with little or no tolerance of ambiguity have the disadvantage to suffer from psychological discomfort and linguistic uncertainty.

There have been many studies dealing with learners' tolerance of ambiguity since O'Connor (1952) used Walk's A Scale to investigate the relationship between tolerance of ambiguity and ethonocentrism. Some studies of ambiguity tolerance deal with the relationship between AT and ethnocentrism or authoritarianism (O'Conner, 1952; Levitt, 1953; Budner, 1962; Ehrlich, 1965; Chapelle, 1983); some refer to AT and learners' rigidity or receptivity of change (MacDonald, 1970; McLain, 1993); some mention about AT and other variables, such as Field Dependence/ Independence (Chapelle \& Roberts, 1986), or strategy use (Ely, 1989); some focuse on AT and second/foreign language success (Pimsleur et al, 1966; Naiman, 1975; MacDonald,1970; Chapelle, 1983; Chapelle \& Roberts, 1986; Chapelle \& Jamison, 1986; Ely, 1986, 1989, Chen, 1989). Subjects of many studies are university students, with an exception in Levitt's (1953), in which 
subjects are elementary school students, and in Naiman et al's (1975), in which subjects are high school students. The most frequently used instruments for measuring AT are Budner's (1962) and Norton's (1975). Findings are various and inconsistent. Nevertheless, except in Pimsleur, et al's (1966) and in Chen's (1989), in which AT is found unrelated to language success, many studies have explored that AT is related to the investigating variable(s) in one way or another. In particular, the relationship between AT and second/foreign has become one of the major concerns in the study of ambiguity tolerance. Especially after Elys' English version of Second Language Tolerance of Ambiguity Scale was developed in 1995, and English has been the "Lingua Franca", studies about the effects of tolerance of ambiguity, together with other factors related to ESL/EFL learning, have become more and more blooming worldwide in EF learning situation than ever before.

\section{Methodology}

Methodology included (1) research design, (2) subjects of the study, (3) research instruments, and (4) procedure. They were described below:

\subsection{Research design}

A case study was used for the research methodology because the focus of attention is the case, not the whole population of cases. In addition, a case study has the advantages of combining qualitative and quantitative data in a complementary way (Stake 1988), and in providing a depth study of a special case as well. "Some case studies are highly impersonal and statistical" (Stake 1988, 256). It is the study of a bounded system, which is in a particular circumstance and with a particular problem, and also gives readers "space" for their own opinions.

\subsection{Subjects of the study}

Subjects were 284 Taiwanese college students, including $188(66 \%)$ English majors and $96(34 \%)$ non-English majors. Among all of the subjects, $81(29 \%)$ were males and 203 $(71 \%)$ were females. Subjects of the study were presented in Table 3.1.

Table 3.1 Subjects of the study

\begin{tabular}{|ll|l|l|l|}
\hline & \multicolumn{2}{|c|}{ majors } & total \\
\cline { 3 - 5 } & & English major & $\begin{array}{l}\text { Non-English } \\
\text { major }\end{array}$ & \\
\hline gender & males & 57 & 21 & 81 \\
& females & 131 & 72 & 203 \\
total & & 188 & 96 & 284 \\
\hline
\end{tabular}

\subsection{Research Instruments}

The research instruments of the study included two questionnaires of Multiple Intelligences (Gardner, 1983) and Ely's Second Language Tolerance of Ambiguity Scale (SLTA) (1995). The former is the most popular one dealing with multiple intelligences, 
while the latter, it was the only scale of tolerance of ambiguity designed specifically for foreign/second language learning context. Particularly, the items represent a broad spectrum of language activities of listening, speaking, reading comprehension, writing, lexical development, pronunciation, and grammar learning (Ely, 1995), which really represent the types of language learning that the students are experiencing.

In addition, to understand the participants' English level to make sure that the scale was grammatically and lexically appropriate for them, students' English test results were used as their English proficiency, namely their English levels of Taiwan College Entrance Advanced Subjects Test (CEAST). The full score of the test was 100 points, and were divided into 15 levels with a range of 6.32 points, for example, Level 15 was ranging from 88.49 to100, while Level 14 was ranging from 82.17 to 88.48 , etc. The English test included two parts, one was reading (56 items, 72 points), and the other was writing (2 translations and 1 writing, 28 points). In Taiwan, to get into colleges, high school seniors (or graduates) can take two official tests every year, one is College Entrance Exam (CEE) or/and College Entrance Advanced Subjects Test (CEAST), held in late January, and the following early July, respectively; the higher the levels/scores, the better college students are granted admission. After realizing the participants' English proficiency was not quite satisfactory (in fact, the mean score of the whole participants was 33.84 points out of 100 points, or level 7.95 out of 15), partly with the intention of avoiding some students' possible misunderstanding of the item contents, and partly "if we have a group of students who all speak the same first language, we can use a translated form of an instrument-noting" (Liu, 2015, p.1875), a bi-lingual English-Chinese version of Multiple Intelligences (MI) and Second Language Tolerance of Ambiguity (SLTA) was adopted in the present study. The details of the instruments of the study were displayed in Table 3.2.

Table 3. 2. Instruments of the study

\begin{tabular}{|c|c|c|c|c|c|c|c|}
\hline $\begin{array}{l}\text { Questionnai } \\
\text { e } \\
\text { l }\end{array}$ & subcategories & Item & Numbe & $\begin{array}{l}\text { Questionnaire } \\
\text { II }\end{array}$ & subcategories & Item & Number \\
\hline \multirow{9}{*}{$\begin{array}{l}\text { Multiple } \\
\text { Intelligence } \\
\text { (MI) } \\
\text { (Gardner, } \\
1983)\end{array}$} & $\begin{array}{l}\text { Logical/ } \\
\text { Mathematical }\end{array}$ & 10 & 01-10 & \multirow{7}{*}{$\begin{array}{l}\text { Second } \\
\text { Language } \\
\text { Tolerance } \\
\text { Ambiguity } \\
\text { (SLTA) } \\
\text { Ely, } 1995\end{array}$} & Listening & 1 & 2 \\
\hline & $\begin{array}{l}\text { Verbal/ } \\
\text { Linguistic }\end{array}$ & 10 & $11-20$ & & Speaking & 1 & 10 \\
\hline & Visual/Spatial & 10 & $21-30$ & & Reading & 3 & $1,6,12$ \\
\hline & Bodily & 10 & $31-40$ & & Writing & 2 & 3,8 \\
\hline & Musical & 10 & $41-50$ & & $\begin{array}{l}\text { Lexical } \\
\text { development }\end{array}$ & 2 & 9,11 \\
\hline & Interpersonal & 10 & $51-60$ & & Pronunciation & 1 & 5 \\
\hline & Intrapersonal & 10 & $61-70$ & & Grammar & 2 & 4,7 \\
\hline & $\begin{array}{l}\text { Universal/ } \\
\text { Naturalist }\end{array}$ & 10 & $71-80$ & \multirow{2}{*}{$\begin{array}{l}\text { English } \\
\text { Levels, } \\
\text { CEAST }^{*}\end{array}$} & \multirow[t]{2}{*}{$\begin{array}{l}\text { Reading+ } \\
\text { writing }\end{array}$} & \multirow[t]{2}{*}{$\begin{array}{l}56+ \\
3\end{array}$} & \\
\hline & Existential & 10 & $81-90$ & & & & \\
\hline
\end{tabular}


*College Entrance Advanced Subjects Test, Taiwan. Scores:72+28=100 points and 1-15 levels

\subsection{Procedure}

The study was conducted to investigate the impacts of gender differences, multiple intelligences (MI) and second language tolerance of ambiguity (SLAT) on English learning. To avoid possible unnecessary misunderstanding, items of Second Language Tolerance of Ambiguity Scale (SLTAS) (Ely, 1995) were displayed in both English and Chinese by the researcher. Three weeks prior to the study, a pilot study was carried out by 28 freshmen, and the Cronbach's alpha internal consistency reliability was found to be .875 . Then, in the late 2015, a total of 317 students in the university (including the 28 pilot-study- takers) were arranged to fill out the two questionnaires of multiple intelligences (MI) and second language tolerance of ambiguity (SLAT). If they agreed to participate in the study, they would sign their names on the answer sheet, if not, they didn't need to do that. Hence, discarding name-blank and incomplete ones, the rest 284 answer sheets $(85.6 \%)$ were remained valid in data analysis phrase. In other words, about $14.4 \%$ of the participants were excluded from the data analysis when investigating factors relating to students' English levels. In the study, students' English Levels of College Entrance Advanced Subject Test (CEAST) on files were used as their English proficiency.

Along with descriptive statistics of mean and standard deviation, the data was analyzed by using The Statistical Package for the Social Science (SPSS) to perform three analyses. First, Pearson product-moment correlation was computed to find out the correlation among 9 subcategories (i.e. 9 intelligences) of multiple intelligences (MI) and 7 subcategories (i.e. 7 language skills) of second language tolerance of ambiguity (SLTA). Then, a Regression Analysis was used to determine (1) if gender differences related to multiple intelligences (MI), MI related to second language tolerance of ambiguity (SLTA), and SLTA related to English levels. Additionally, a $t$-Test was calculated to investigate whether there were significant differences on multiple intelligences, tolerance of ambiguity, and English levels between males and females.

\section{Findings and Results}

Findings of the study included (1) reliability of the research instrument, (2) descriptive analysis of students' multiple intelligences (MI), second language tolerance of ambiguity (SLTA), and English levels, (3) analysis of multiple intelligences (MI), (4) analysis of second language tolerance of ambiguity (SLTA), (5) gender differences of multiple intelligences (MI), second language tolerance of ambiguity (SLTA), and English levels, (6). regression analysis of multiple intelligences $(\mathrm{MI})$, second language tolerance of ambiguity (SLTA), and gender differences, predictive to English levels, and (7) relation of gender difference, subcategories of multiple intelligences (MI), second language tolerance of ambiguity (SLTA), and English levels. They were described below: 


\subsection{Reliability of Multiple Intelligences (MI) and Second Language Tolerance of Ambiguity \\ (SLTA)}

The reliability of Multiple Intelligences (MI) (Gardner, 1983) and The Second Language Tolerance of Ambiguity Scale (SLTAS)(Ely, 1995) was Cronbach's Alpha .919 (N of Cases $=90$ ) and .895 ( $\mathrm{N}$ of Cases=12), respectively. "If a test were perfectly reliable, the reliability coefficient would be 1,00. .However, no test is perfect reliable." (Gay \& Airasian, 2003, p.141). Hence, the results of the Cronbach's Alpha internal consistency reliability .919 and .895 indicated that the research instruments of the study were quite reliable. The finding was presented in Table 4.1.

Table 4.1. Reliability of the research instruments

\begin{tabular}{|l|l|l|}
\hline \multicolumn{1}{|c|}{ questionnaire } & $\begin{array}{l}\text { Cronbach's } \\
\text { Alpha }\end{array}$ & N of Items \\
\hline Multiple intelligences (MI) & .919 & 90 \\
\hline $\begin{array}{l}\text { Second Language Tolerance of Ambiguity } \\
\text { (SLTA) }\end{array}$ & .895 & 12 \\
\hline
\end{tabular}

\subsection{Descriptive analysis of students' multiple intelligences (MI), second language tolerance of ambiguity (SLTA), and English levels}

The mean of the English levels was 7.95 out of 15, ranging from level 3 (ranging 12.65-18.96 points) to level 13 (75.85-82.16 points), and the highest level was 15 . Referring to students' second language tolerance of ambiguity, the mean score was 2.70 out of 4.00, which was regarded as moderate level, inclining to low level of second language tolerance of ambiguity (SLTA). As for multiple intelligences (MI), the mean score was 3.25 out of 5.00. The descriptive analysis of students' English levels, second language tolerance of ambiguity (SLTA), and multiple intelligences (MI) was presented in Table 4.2.

Table 4.2. Descriptive analysis of students' English levels, SLTA and MI

\begin{tabular}{|c|c|c|c|c|c|}
\hline & $\mathrm{N}$ & Min & Max & $M$ & SD \\
\hline English levels & 155 & 3.00 & 13.00 & 7.3742 & 1.9387 \\
\hline $\begin{array}{l}\text { Tolerance of } \\
\text { Ambiguity } \\
\text { Multiple intelligences }\end{array}$ & $\begin{array}{l}284 \\
273\end{array}$ & $\begin{array}{l}1.00 \\
1.00\end{array}$ & $\begin{array}{l}5.00 \\
4.34\end{array}$ & $\begin{array}{l}2.7518 \\
3.3066\end{array}$ & $\begin{array}{l}.55498 \\
.51778\end{array}$ \\
\hline
\end{tabular}

\subsection{Analysis of multiple intelligences (MI)}

The following analysis included descriptive analysis of mean and standard deviation of multiple intelligences (MI), correlation among subcategories of multiples intelligences (MI), and regression analysis of multiple intelligences (MI) predicting second language tolerance of ambiguity (SLTA) and English levels. They were described below: 


\subsubsection{Mean and standard deviation of multiple intelligences (MI)}

The findings revealed that students were stronger with those intelligences as Existential Intelligence (1 $\left.{ }^{\text {st }}\right)$, Musical/Rhythmic Intelligence $\left(2^{\text {nd }}\right)$, Intrapersonal Intelligence (3rd), and Visual/Spatial Intelligence $\left(4^{\text {th }}\right)$, and interpersonal Intelligences $\left(5^{\text {th }}\right)$. On the other hand, they were weaker with Verbal/ Linguistic Intelligence $\left(6^{\text {th }}\right)$, Bodily Intelligence $\left(7^{\text {th }}\right)$, Logical/Mathematical Intelligence $\left(8^{\text {th }}\right)$, and Universal/Naturalist Intelligence $\left(9^{\text {th }}\right)$. The findings were displayed in Table 4.3.1.

Table 4.3.1. Mean and standard deviation of Multiple Intelligences (MI)

\begin{tabular}{|l|l|l|l|l|l|l|}
\hline & $\mathrm{N}$ & $\mathrm{Min}$ & $\mathrm{Max}$ & $\mathrm{M}$ & $\mathrm{SD}$ & rank \\
\hline Logical/Mathematical intelligence & 283 & 1.00 & 5.00 & 2.9258 & .75878 & $\mathbf{( 8 )}$ \\
Verbal/Linguistic intelligence & 283 & 1.00 & 5.00 & 3.2396 & .71230 & $\mathbf{( 6 )}$ \\
Visual/Spatial intelligence & 283 & 1.00 & 5.00 & 3.4442 & .71741 & $\mathbf{( 4 )}$ \\
Bodily intelligence & 282 & 1.00 & 5.00 & 3.1301 & .75570 & $\mathbf{( 7 )}$ \\
Musical/Rhythmic intelligence & 284 & 1.00 & 5.00 & 3.5658 & .85924 & $\mathbf{( 2 )}$ \\
Interpersonal intelligence & 283 & 1.00 & 5.00 & 3.2816 & .74048 & $\mathbf{( 5 )}$ \\
Intrapersonal intelligence & 282 & 1.00 & 5.00 & 3.4766 & .66441 & $\mathbf{( 3 )}$ \\
Universal/Naturalist intelligence & 284 & 1.00 & 5.00 & 2.8461 & .77507 & $\mathbf{( 9 )}$ \\
Existential intelligence & 278 & 1.00 & 5.00 & 3.7543 & .74318 & $\mathbf{( 1 )}$ \\
All MI & 273 & 1.00 & 4.88 & 3.3066 & .51778 & \\
\hline
\end{tabular}

\subsubsection{Correlation among subcategories of multiple intelligences (MI)}

The findings revealed that all the subcategories of multiple intelligences (MI) were strongly correlated to one another $(\mathrm{p}<.01)$. The findings were presented in Table 4.3.2.

Table 4.3.2. Correlation among subcategories of multiple intelligences

\begin{tabular}{|c|c|c|c|c|c|c|c|c|c|c|}
\hline & & logical & verbal & spatial & bodily & musical & $\begin{array}{l}\text { interper } \\
\text { sonal }\end{array}$ & $\begin{array}{l}\text { intraper } \\
\text { sonal }\end{array}$ & $\begin{array}{l}\text { univers } \\
\text { al }\end{array}$ & existential \\
\hline \multirow[t]{3}{*}{ logical } & $\begin{array}{l}\text { Pearson } \\
\text { Correlatio } \\
n\end{array}$ & 1 & $\left..360{ }^{(* *}\right)$ & $.466\left(^{* *}\right)$ & $.347\left(^{* *}\right)$ & $.173\left({ }^{* *}\right)$ & $.178\left(^{(*)}\right.$ & $.258\left({ }^{* *}\right)$ & $.247\left(^{* *}\right)$ & $\left..205^{(* *}\right)$ \\
\hline & $\begin{array}{l}\text { Sig } \\
\text { (two-taile } \\
\text { d) }\end{array}$ & & .000 & .000 & .000 & .004 & .003 & .000 & .000 & .001 \\
\hline & $N$ & 283 & 283 & 283 & 282 & 283 & 282 & 281 & 283 & 277 \\
\hline \multirow[t]{3}{*}{ verbal } & Pearson & $\left..3600^{\star \star}\right)$ & 1 & $.482\left({ }^{* *}\right)$ & $.402\left(^{(* *}\right)$ & $.438\left(^{* \star}\right)$ & $.415\left(^{* *}\right)$ & $\left..4911^{(*}\right)$ & $\left..343^{(* *}\right)$ & $.422\left({ }^{* *}\right)$ \\
\hline & $\begin{array}{l}\text { Correlatio } \\
\text { n Sig } \\
\text { (two-taile } \\
\text { d) }\end{array}$ & .000 & & .000 & .000 & .000 & .000 & .000 & .000 & .000 \\
\hline & & 283 & 283 & 283 & 282 & 283 & 282 & 281 & 283 & 277 \\
\hline \multirow{3}{*}{ spatial } & $\begin{array}{l}\text { Pearson } \\
\text { Correlatio } \\
\text { n } \\
\text { Sig }\end{array}$ & $.466\left({ }^{* *}\right)$ & $.482\left(^{* \star}\right)$ & 1 & $\left..583^{(* *}\right)$ & $.449\left(^{(* *}\right)$ & $.373\left(^{* *}\right)$ & $.504\left({ }^{* \star}\right)$ & $.407\left(^{* *}\right)$ & $\left..493^{(* *}\right)$ \\
\hline & $\begin{array}{l}\text { (two-taile } \\
\text { d) }\end{array}$ & .000 & .000 & & .000 & .000 & .000 & .000 & .000 & .000 \\
\hline & $\mathrm{N}$ & 283 & 283 & 283 & 282 & 283 & 282 & 281 & 283 & 277 \\
\hline
\end{tabular}




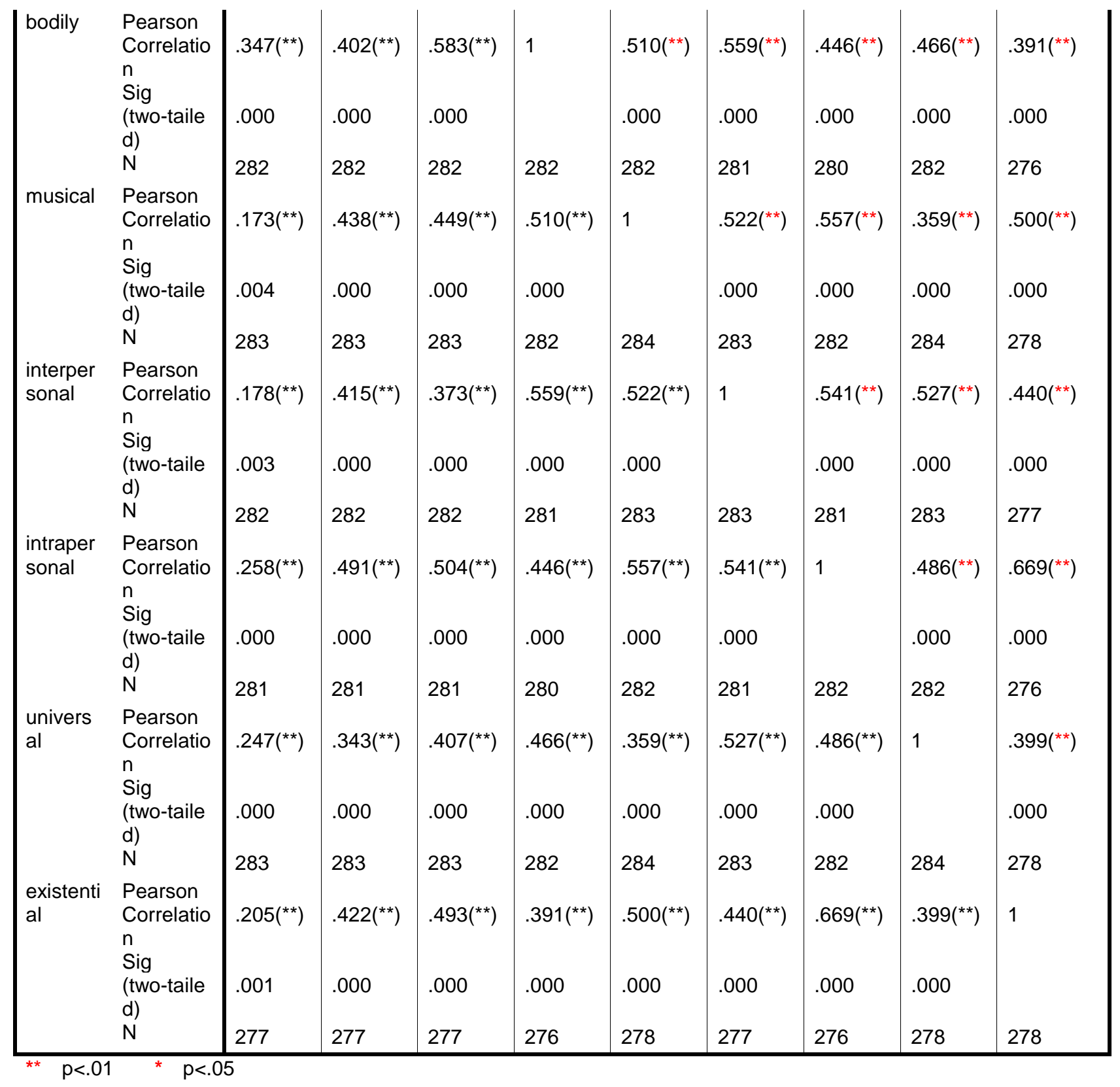

\subsection{Analysis of Second Language Tolerance of Ambiguity (SLTA)}

The following analysis included descriptive analysis of mean and standard deviation of second language tolerance of ambiguity (SLTA), correlation among subcategories of second language tolerance of ambiguity (SLTA), and regression analysis of subcategories of SLAT predictive to English levels. They were described below:

\subsubsection{Subcategories of Second Language Tolerance of Ambiguity Scale (SLTA)}

Based on the content of each item of Second Language Tolerance of Ambiguity (SLTA), all of the 12 items were divided into 7 language components as listening (item 2), speaking (item 10), reading (items 1, 6, 12), writing (items 3, 8), lexical development (items 9, 11), 
pronunciation (item 5), and grammar.(items 4,7 ). The findings revealed that students were lower tolerant of ambiguity in Writing $(M=2.96)$, Pronunciation $(M=2.86)$, and Listening $(M=2.80)$, followed by Grammar $(M=2.79)$, Speaking $(M=2.75)$, Lexical development $(\mathrm{M}=2.68)$, and Reading $(\mathrm{M}=2.54)$. The findings were displayed in Table 4.4.1.

Table 4.4.1. Subcategories of Second Language Tolerance of Ambiguity Scale (SLTAS)

\begin{tabular}{|l|l|l|l|l|l|l|}
\hline & N & Min & Max & M & SD & rank \\
\hline AT Listening & 284 & 1.00 & 5.00 & 2.8028 & .79075 & $\mathbf{( 3 )}$ \\
AT Speaking & 284 & 1.00 & 5.00 & 2.7535 & .83380 & $\mathbf{( 5 )}$ \\
AT Reading & 284 & 1.00 & 5.00 & 2.5493 & .61928 & $\mathbf{( 7 )}$ \\
AT Writing Lexical & 284 & 1.00 & 5.00 & 2.9630 & .66290 & $\mathbf{( 1 )}$ \\
AT & 284 & 1.00 & 5.00 & 2.6849 & .68823 & $\mathbf{( 6 )}$ \\
development & 284 & 1.00 & 5.00 & 2.7993 & .90065 & $\mathbf{( 4 )}$ \\
AT Grammar & 284 & 1.00 & 5.00 & 2.8609 & .66262 & $\mathbf{( 2 )}$ \\
AT Pronunciation & 284 & 1.00 & 5.00 & 2.7518 & .55498 & \\
All SLAT & & &
\end{tabular}

${ }^{*}$ In the study, the higher the score, the lower the tolerance of ambiguity

\subsubsection{Correlation among subcategories of tolerance of ambiguity}

The findings showed that all the seven language skills were strongly correlated to one another $(p<.01)$, which were presented in Table 4.4.2.

Table 4.4.2 Co-relation among subcategories of tolerance of ambiguity

\begin{tabular}{|c|c|c|c|c|c|c|c|c|}
\hline & & $\begin{array}{l}\text { AT } \\
\text { Listenin } \\
\mathrm{g}\end{array}$ & $\begin{array}{l}\text { AT } \\
\text { speaking }\end{array}$ & $\begin{array}{l}\mathrm{AT} \\
\text { reading }\end{array}$ & $\begin{array}{l}\text { AT } \\
\text { writing }\end{array}$ & $\begin{array}{l}\text { AT } \\
\text { Lexical } \\
\text { develop }\end{array}$ & $\begin{array}{l}\text { AT } \\
\text { grammar }\end{array}$ & $\begin{array}{l}\text { AT } \\
\text { pronunciati } \\
\text { on }\end{array}$ \\
\hline \multirow[t]{3}{*}{ AT listening } & $\begin{array}{l}\text { Pearson } \\
\text { correlation }\end{array}$ & 1 & $.473\left({ }^{* *}\right)$ & $.628\left({ }^{* *}\right)$ & $.667\left(^{* \star}\right)$ & $.564\left({ }^{* \star}\right)$ & $.548\left({ }^{\star \star}\right)$ & $.435\left(^{* *}\right)$ \\
\hline & Sig (two-tailed) & & .000 & .000 & .000 & .000 & .000 & .000 \\
\hline & $\mathrm{N}$ & 284 & 284 & 284 & 284 & 284 & 284 & 284 \\
\hline \multirow[t]{3}{*}{$\begin{array}{l}\text { AT } \\
\text { speaking }\end{array}$} & $\begin{array}{l}\text { Pearson } \\
\text { correlation }\end{array}$ & $.473\left(^{* *}\right)$ & 1 & $.523\left({ }^{\star *}\right)$ & $.473\left({ }^{* \star}\right)$ & $.606\left(^{* \star}\right)$ & $.488\left(^{* *}\right)$ & $.419\left(^{* *}\right)$ \\
\hline & Sig (two-tailed) & .000 & & .000 & .000 & .000 & .000 & .000 \\
\hline & $\mathrm{N}$ & 284 & 284 & 284 & 284 & 284 & 284 & 284 \\
\hline \multirow[t]{3}{*}{ AT reading } & $\begin{array}{l}\text { Pearson } \\
\text { correlation }\end{array}$ & $.628\left(^{* \star}\right)$ & $.523\left({ }^{\star \star}\right)$ & 1 & $.557\left({ }^{* \star}\right)$ & $.692\left({ }^{\star \star}\right)$ & $.566\left(^{* \star}\right)$ & $.475\left(^{\star *}\right)$ \\
\hline & Sig (two-tailed) & .000 & .000 & & .000 & .000 & .000 & .000 \\
\hline & $\mathrm{N}$ & 284 & 284 & 284 & 284 & 284 & 284 & 284 \\
\hline \multirow[t]{3}{*}{ AT writing } & $\begin{array}{l}\text { Pearson } \\
\text { correlation }\end{array}$ & $.667\left(^{* \star}\right)$ & $.473\left({ }^{\star *}\right)$ & $.557\left(^{\star \star}\right)$ & 1 & $.561\left(^{* \star}\right)$ & $.630\left(^{* *}\right)$ & $.473\left({ }^{* *}\right)$ \\
\hline & Sig (two-tailed) & .000 & .000 & .000 & & .000 & .000 & .000 \\
\hline & $\mathrm{N}$ & 284 & 284 & 284 & 284 & 284 & 284 & 284 \\
\hline \multirow{3}{*}{$\begin{array}{l}\text { AT lexical } \\
\text { developme } \\
\text { nt }\end{array}$} & $\begin{array}{l}\text { Pearson } \\
\text { correlation }\end{array}$ & $.564\left(^{\star \star *}\right)$ & $.606\left(^{* \star}\right)$ & $.692\left(^{* \star}\right)$ & $\left..5611^{* \star}\right)$ & 1 & $.620\left(^{* *}\right)$ & $.496\left(^{* *}\right)$ \\
\hline & Sig (two-tailed) & .000 & .000 & .000 & .000 & & .000 & .000 \\
\hline & $\mathrm{N}$ & 284 & 284 & 284 & 284 & 284 & 284 & 284 \\
\hline $\begin{array}{l}\text { AT } \\
\text { grammar }\end{array}$ & $\begin{array}{l}\text { Pearson } \\
\text { correlation }\end{array}$ & $.548\left(^{* \star}\right)$ & $.488\left(^{\star \star *}\right)$ & $.566\left(^{* \star}\right)$ & $.630\left(^{* \star}\right)$ & $.620\left(^{* \star}\right)$ & 1 & $.498\left(^{* *}\right)$ \\
\hline
\end{tabular}




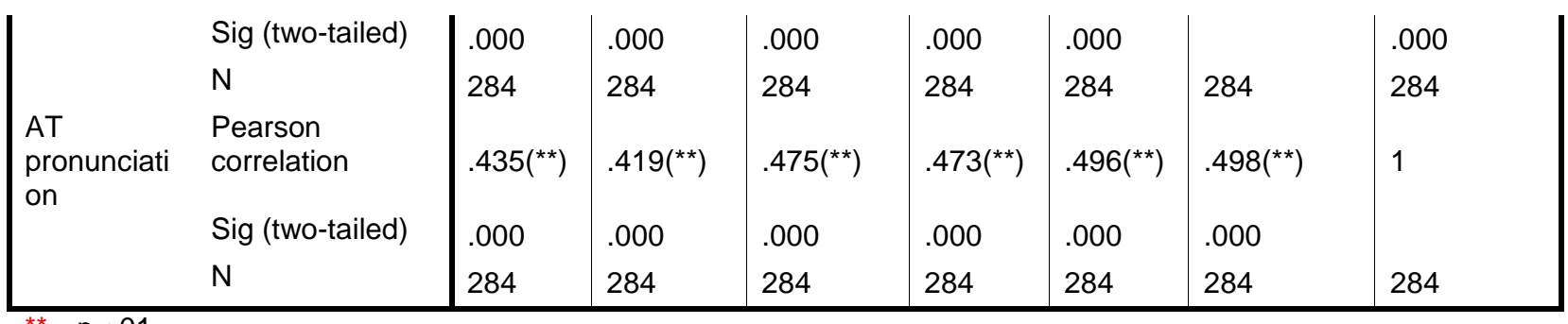

$\mathrm{p}<.01$

\subsection{Gender differences of multiple intelligences (MI), second language tolerance of ambiguity (SLTA), and English levels}

The analysis included gender differences of multiple intelligences (MI), second language tolerance of ambiguity (SLTA), and English levels. They were described below:

\subsubsection{Gender differences of multiple intelligences (MI)}

Findings showed that females had higher means in verbal/linguistic intelligence $(p<.05)$ and musical intelligence $(p<.05)$ than males. Though males had higher means in logical/mathematic intelligence, visual/spatial intelligence, bodily intelligence, and universal/naturalist intelligence, yet none reached a significant level. The findings were displayed in Table 4.5.1.

Table 4.5.1. Gender differences of Multiple Intelligences (MI)

\begin{tabular}{|c|c|c|c|c|c|}
\hline \\
\hline Variable & gender & $\mathrm{N}$ & $\mathrm{M}$ & SD & Sig \\
\hline \multirow[t]{2}{*}{ Logical/Mathematical intelligence } & male & 81 & 3.0519 & .85471 & \multirow{2}{*}{.077} \\
\hline & female & 202 & 2.8752 & .71277 & \\
\hline \multirow[t]{2}{*}{ Verbal/Linguistic intelligence } & male & 81 & 3.1000 & .73705 & \multirow{2}{*}{.037} \\
\hline & female & 202 & 3.2955 & .69614 & \\
\hline \multirow[t]{2}{*}{ Visual/Spatial intelligence } & male & 81 & 3.4617 & .79366 & \multirow{2}{*}{.795} \\
\hline & female & 202 & 3.4371 & .68644 & \\
\hline \multirow[t]{2}{*}{ Bodily intelligence } & male & 80 & 3.2375 & .79291 & \multirow{2}{*}{.134} \\
\hline & female & 202 & 3.0876 & .73815 & \\
\hline \multirow[t]{2}{*}{ Musical/Rhythmic intelligence } & male & 81 & 3.3889 & .83606 & \multirow{2}{*}{.028} \\
\hline & female & 203 & 3.6365 & .86020 & \\
\hline \multirow[t]{2}{*}{ Interpersonal intelligence } & male & 81 & 3.2519 & .76781 & \multirow{2}{*}{.699} \\
\hline & female & 202 & 3.2936 & .73085 & \\
\hline \multirow[t]{2}{*}{ Intrapersonal intelligence } & male & 80 & 3.4313 & .75433 & \multirow{2}{*}{.472} \\
\hline & female & 202 & 3.4946 & .62639 & \\
\hline Universal/Naturalist intelligence & male & 81 & 2.9815 & .82978 & .063 \\
\hline
\end{tabular}




\begin{tabular}{|l|l|l|l|l|l|}
\hline & female & 203 & 2.7921 & .74743 & \\
\hline Existential intelligence & male & 80 & 3.7113 & .86654 & \multirow{2}{*}{.540} \\
\cline { 2 - 7 } & female & 198 & 3.7717 & .68878 & \\
\hline All MI & male & 78 & 3.2870 & .62630 & \multirow{2}{*}{.069} \\
\cline { 2 - 6 } & female & 195 & 3.3144 & .46903 & \\
\hline
\end{tabular}

\subsubsection{Gender differences of second language tolerance of ambiguity (SLTA) and} English levels

It was found that except for second language tolerance of ambiguity (SLTA) of listening, while females had higher than males $(p<.05)$, there was no significant difference in both other language skills and English levels between males and females. Although males had higher mean in tolerance of ambiguity of speaking, yet, it didn't reach a significant level. The findings were presented in Table 4.5.2. 
Table 4.5.2. Gender differences of second language tolerance of Ambiguity (SLTA) and English levels

\begin{tabular}{|c|c|c|c|c|c|}
\hline & & & & & \\
\hline variable & gender & N & $M$ & SD & sig \\
\hline AT Listening & male & 81 & 2.6543 & .82402 & .045 \\
\hline & female & 203 & 2.8621 & .77120 & \\
\hline AT Speaking & male & 81 & 2.8519 & .89598 & .210 \\
\hline & female & 203 & 2.7143 & .80662 & \\
\hline AT Reading & male & 81 & 2.5021 & .66692 & .418 \\
\hline & female & 203 & 2.5681 & .59990 & \\
\hline AT Writing & male & 81 & 2.9444 & .72887 & .766 \\
\hline & female & 203 & 2.9704 & .63645 & \\
\hline AT Lexical development & male & 81 & 2.6481 & .74349 & .571 \\
\hline & female & 203 & 2.6995 & .66627 & \\
\hline AT Grammar & male & 81 & 2.8272 & .67157 & .589 \\
\hline & female & 203 & 2.8744 & .66021 & \\
\hline AT Pronunciation & male & 81 & 2.6790 & .91961 & .155 \\
\hline & female & 203 & 2.8473 & .89073 & \\
\hline All AT & male & 81 & 2.7109 & .58245 & .434 \\
\hline & female & 203 & 2.7681 & .54426 & \\
\hline English levels & male & 40 & 7.4750 & 1.96100 & .635 \\
\hline & female & 109 & 7.3028 & 1.96027 & \\
\hline
\end{tabular}

\subsection{Regression Analysis}

\subsubsection{Regression Analysis of multiple intelligences (MI), second language tolerance of ambiguity (SLTA), and gender differences predictive to English levels}

A standard regression analysis was performed between the dependent variables English levels) and independent variables (multiple intelligences, second language tolerance of ambiguity, and gender difference). The analysis was performed using SPSS regression. Findings showed that among the three factors, only second language tolerance of ambiguity (SLTA) was predictive to English levels $(t=-3.462, \mathrm{sig}=.001)$ negatively. The findings were presented in Table 4.6.1. 
Table 4.6.1. Regression analysis of multiple intelligences (MI), second language tolerance of ambiguity (SLTA), and gender difference predictive to English levels

\begin{tabular}{|c|c|c|}
\hline \multirow[b]{2}{*}{ variable } & \multicolumn{2}{|c|}{ English level } \\
\hline & $\mathrm{t}$ & sig \\
\hline (Constant) & 5.349 & .000 \\
\hline Multiple intelligences (MI) & -.023 & .981 \\
\hline $\begin{array}{c}\text { Second Language Tolerance of Ambiguity } \\
\text { (SLTA) }\end{array}$ & -3.462 & .001 \\
\hline genders & .397 & .692 \\
\hline
\end{tabular}

\subsubsection{Regression analysis of subcategories of multiple intelligences (MI) predictive} to second language tolerance of ambiguity (SLTA) and English levels

Among the 9 subcategories of multiple intelligences (MI), it was found that variables predictive to second language tolerance of ambiguity (SLTA) were logical/mathematic intelligence $(\mathrm{t}=5.227, \mathrm{sig}=.000)$ and visual/spatial intelligence $(\mathrm{t}=-2.818, \mathrm{sig}=.005)$ negatively. But, none of the subcategories of $\mathrm{Ml}$ was predictive to English levels. The findings were presented in Table 4.6.2.

Table 4.6.2. Regression analysis of MI predicting SLTA, English levels

\begin{tabular}{|c|c|c|c|c|}
\hline \multirow[b]{2}{*}{ variable } & \multicolumn{2}{|c|}{ Tolerance of ambiquity } & \multicolumn{2}{|c|}{ English level } \\
\hline & $t$ & sig & $t$ & sig \\
\hline (Constant) & 9.019 & .000 & 7.394 & .000 \\
\hline Logical/Mathematical intelligence & 5.227 & .000 & -1.373 & .172 \\
\hline Verbal/Linguistic intelligence & -1.554 & .121 & .983 & .328 \\
\hline Visual/Spatial intelligence & -2.818 & .005 & -.236 & .814 \\
\hline Bodily intelligence & 1.045 & 297 & -.615 & .540 \\
\hline Musical/Rhythmic intelligence & 1.197 & .232 & .340 & .734 \\
\hline Interpersonal intelligence & .948 & .344 & -1.788 & .076 \\
\hline Intrapersonal intelligence & -.024 & .981 & 1.170 & .244 \\
\hline Universal/Naturalist intelligence & .182 & .856 & .637 & .525 \\
\hline Existential intelligence & 1.627 & .105 & -.168 & .867 \\
\hline
\end{tabular}

4.6.3. Regression analysis of subcategories of second language tolerance of ambiguity (SLTA) predictive to English s levels

The findings showed that among the 7 subcategories of second language 
tolerance of ambiguity (SLTA), only tolerance of ambiguity of reading was predictive to English levels $(t=-2.113$, sig=.036) negatively. The findings were displayed in Table 4.6.3.

Table 4.6.3. Regression analysis of subcategories of SLTA predictive English levels

\begin{tabular}{|l|l|l|}
\hline \multirow{2}{*}{ variable } & English level \\
\cline { 2 - 3 } & t & sig \\
\hline (Constant) & 11.734 & .000 \\
\hline AT Listening & .554 & .581 \\
\hline AT Speaking & -.079 & .937 \\
\hline AT Reading & -2.113 & .036 \\
\hline AT Writing & .236 & .813 \\
\hline AT Lexical development & -.543 & .588 \\
\hline AT Grammar & -.029 & .977 \\
\hline AT Pronunciation & -.315 & .753 \\
\hline
\end{tabular}

$$
{ }^{* *} p<.01 \quad{ }^{*} p<.05
$$

\subsection{Relation of gender difference, subcategories of multiple intelligences, second language tolerance of ambiguity, and English levels}

By analyzing gender differences, the subcategories of multiple intelligences (MI) and second language tolerance of ambiguity (SLAT), predicting to English levels, findings showed that relation of gender difference, subcategories of multiple intelligences (MI), second language tolerance of ambiguity (SLAT), and English levels did exist in one way or another. It was shown that on the one hand, some subcategories of multiple intelligences (MI) were predictive to some of subcategories of second language tolerance of ambiguity (SLAT). On the other hand, some subcategory of second language tolerance of ambiguity (SLTA) was predictive to English levels. The relation of gender difference, multiple intelligences (MI), second language tolerance of ambiguity (SLAT) and English levels was shown in Figure 1, and the conclusion was shown in Figure 2. 
Figure 1. Relation of gender difference, MI, SLAT, and English level

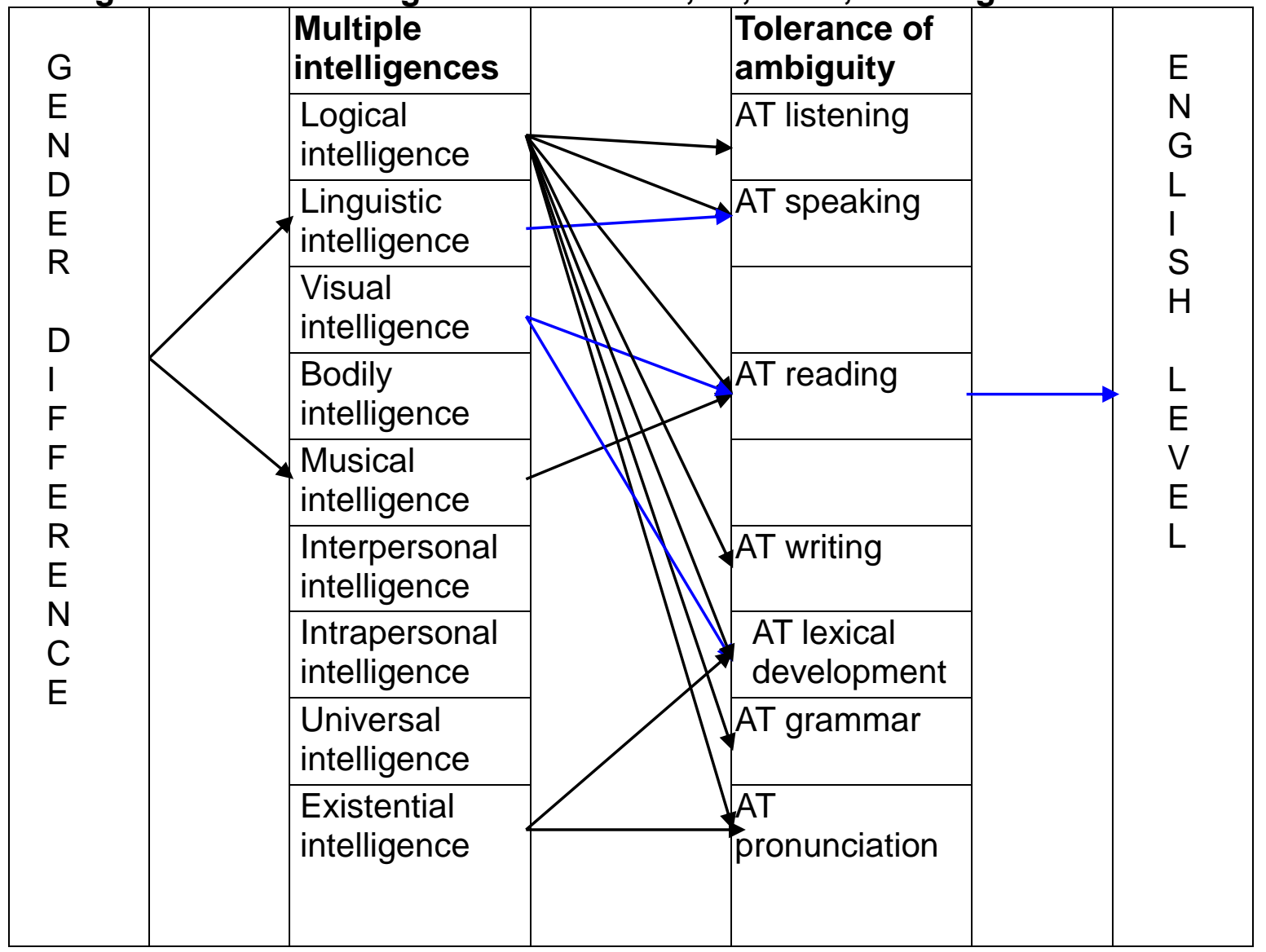

${ }^{*}$ Females were stronger with verbal/linguistic intelligence $(p<.05)$ and musical intelligence $(p<.05)$.

*Logical/Mathematic intelligence was predictive to all the skills of language learning, including: listening ( $\mathrm{t}=3.347, \mathrm{sig}=.001)$, speaking $(\mathrm{t}=3.889$, sig=.000), reading $(\mathrm{t}=4.226$, sig $=.000)$, writing $(\mathrm{t}=1.478, \mathrm{sig}=.000)$, lexical development $(\mathrm{t}=4.555, \mathrm{sig}=.000)$, grammar $(\mathrm{t}=3.844, \mathrm{sig}=.000)$, and pronunciation $(\mathrm{t}=3.592$, sig=.000).

*Verbal/Linguistic intelligence was negatively predictive to speaking $(\mathrm{t}=-2.155 . \mathrm{sig}=.032)$.

*Visual/Spatial intelligence was negatively predictive to both reading ( $\mathrm{t}=-3.644$, $\mathrm{sig}=.000)$, and lexical development $(\mathrm{t}=-2.976, \mathrm{sig}=.003)$.

*Musical intelligence was predictive to reading ( $\mathrm{t}=2.131$, sig=.034).

${ }^{*}$ Intrapersonal intelligence was predictive to speaking $(t=2.599$, sig=.010).

${ }^{*}$ Existential intelligence was predictive to lexical development $(\mathrm{t}=1.985, \mathrm{sig}=.048)$ and pronunciation $(\mathrm{t}=2.382$, sig $=.018)$.

*Second language tolerance of ambiguity of reading was negatively predictive to English level ( $\mathrm{t}=-2.113$, sig=.036). 
Figure 2. Gender, Multiple intelligence, SLTA and English

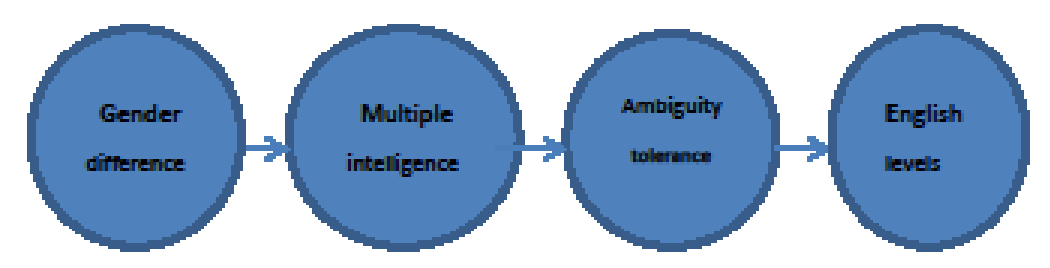

\section{Conclusion}

Conclusion included summary, discussion, and implication. They were described below:

\subsection{Summary and discussion}

The study aimed to investigate, from an aspect of multiple intelligences (MI) and second language tolerance of ambiguity (SLTA), to see why females were always regarded as better language learners. A total of 284 college students served as subjects of the study, including 81 males and 203 females. They helped to fill out the questionnaires of Multiple Intelligences (MI) (Gardner, 1983) and Second Language Tolerance of Ambiguity Scale (SLTAS) (Ely, 1995) (English-Chinese version). In addition, their English levels of Taiwan College Entrance Exam were adopted as their English proficiency. In addition, descriptive analysis, $t$-Test, ANOVA, and regression analysis were analyzed by the Statistical Package for the Social Science (SPSS).

The findings revealed that students were stronger with those intelligences as Existential Intelligence ( $\left.1^{\text {st }}\right)$, Musical/Rhythmic Intelligence $\left(2^{\text {nd }}\right)$, Intrapersonal Intelligence (3rd), and Visual/Spatial Intelligence $\left(4^{\text {th }}\right)$, and Interpersonal Intelligences $\left(5^{\text {th }}\right)$. On the other hand, they were weaker with Verbal/ Linguistic Intelligence $\left(6^{\text {th }}\right)$. Bodily Intelligence $\left(7^{\text {th }}\right)$, Logical/Mathematical Intelligence $\left(8^{\text {th }}\right)$, and Universal/Naturalist Intelligence $\left(9^{\text {th }}\right)$.

In addition, students were regarded as Moderate tolerant of ambiguity $(M=2.75$ out of 4.00). They were more tolerant of ambiguity in "receptive" areas, particularly in reading $(\mathrm{M}=2.54, \mathrm{SD}=.61)$, and less tolerant of ambiguity in "productive" skills, especially in writing $(\mathrm{M}=2.96, \mathrm{SD}=.66)$ (in the study, the higher the score, the lower the tolerance of ambiguity). As the 12-item Second Language Tolerance of Ambiguity Scale (SLTAS) (Ely, 1995) could be divided into 7 language components, based on the results, it was clear to understand why our students felt more uncomfortable in facing the uncertainty, lacking of determinacy dwarfed by that inherent in doing writing $\left(1^{\text {st }}\right)$, pronunciation $\left(2^{\text {nd }}\right)$, and listening $\left(3^{\text {rd }}\right)$. Comparatively, since they were in an EFL situation, students were more tolerant of ambiguity in reading $\left(7^{\text {th }}\right)$, lexical development $\left(6^{\text {th }}\right)$, speaking $\left(5^{\text {th }}\right)$, and grammar $\left(4^{\text {th }}\right)$. The results were keeping with some other studies conducted in EFL fields, such as Karamia (1999), Kamran, (2011), and Marzban, et.al (2012).

The study found that a correlation among multiple intelligences, tolerance of ambiguity, and English proficiency did exist. Some subcategories of multiple intelligences, such as 
Logical/ Mathematic intelligence, Verbal/Linguistic intelligence, Spatial/Visual intelligence, Musical intelligence, and Existential intelligence, were predictive to tolerance of ambiguity either positively or negatively, and led to English levels at the end.

Regarding to gender differences, females were with stronger verbal/linguistic intelligences $(p<.05)$ and musical intelligence $(p<.05)$. Though males had higher means in visual/spatial intelligence, and universal/naturalist intelligences, yet the differences didn't reach a significant level. Furthermore, some subcategories of intelligences were found to be related to second language tolerance of ambiguity (SLTA) and led to English level to the end. Particularly, as mentioned, in addition to verbal/linguistic intelligences, females were with stronger musical intelligence, which was found to be predictive to second language tolerance of ambiguity (SLTA) of reading negatively, and which led to English levels at the end negatively. In other words, females were with stronger linguistic intelligence and musical intelligence which was related to more tolerant of ambiguity of reading, and had better English level at the end. Hence, with the relation of gender differences, multiple intelligences (MI), and second language tolerance of ambiguity (SLTA), it's supported that females were always regarded as better language learners and could explain why females were always proved to be better language learners (Oxford, 1993, Cheng, et al, 2010).

All came to the answer to the question why females were always regarded as better language learners because they were with stronger Verbal/Linguistic intelligence and more tolerant of ambiguity. Clearly, in the study, the answer was positive. But one thing also clear was that second/foreign learning is really "a multi-faceted task" (Chapelle \& Roberts, 1986, p.44), and to be a successful language learner, in addition to stronger Verbal/Linguistic intelligences, more tolerance of ambiguity, such "predispositions" (Jamieson, 1992) as motivation, attitude, anxiety, field dependence/independence, cognitive styles and learning strategies, all still need to be taken into account.

\subsection{Implications}

The results of the investigation of the relation of multiple intelligences (MI), second language tolerance of ambiguity (SLTA) and English level could be used to help students be familiar with their multiple intelligences, and be aware of the existence of uncertainty in language learning situation. Also, the findings of the strong correlation among all subcategories of multiple intelligences (MI) and second language tolerance of ambiguity (SLTA) could be used to convince students to become more interested in developing more favorable attitude and motivational intensity. By so doing, students may make the best use of their intelligence strengths, use more language learning strategies, become more tolerant of ambiguity, interpret unclear information more properly and become less anxious in foreign language learning. As for teachers, it is hoped that teachers can play the role as a "language coach" (Cohen, 2003), to provide all students equal opportunities to use their strengths to learn. In addition, teachers should act as active agents in the learning process to help students know that language learning is really "a multi-faceted task" (Chapelle \& Roberts, 1986, p.44), anxiety-provoking, and a little ambiguity can go a long way. Most importantly, appropriate curriculum design, teaching activities, and integrative evaluation should be provided and met, together with such "predispositions" (Jamieson, 1992) as 
motivation, attitude, anxiety, field dependence/independence, cognitive styles and learning strategies, all need to be taken into account.

\section{References}

Armstrong, Thomas (2000). Multiple intelligences in the classroom. The Association for Supervision and Curriculum Development (ASCD).

Brown, H. D. (1980). Principles of language learning and teaching. Englewood Cliffs, NJ: Prentice-Hall.

$\mathrm{Bu}$, L.N. (2007). The influence of ambiguity tolerance on Chinese college students during their English learning. Unpublished MA thesis. Xi'an Electronics and Technology University, China.

Budner, S. (1962). Intolerance of ambiguity as a personality variable. Journal of Personality, 30, 29-50.

Canale, M. \& Swain, M. (1980). Theoretical bases of communicative approaches to second language teaching and testing. Applied Linguistics, 1, 1-47.

Chapelle, C. (1983). The relationship between ambiguity tolerance and success in acquiring English as a second language in adult learners. Unpublished doctoral dissertation, University of Illinois at Urbana-Champaign.

Chapelle, C., \& Roberts, C. (1986). Ambiguity tolerance and field independence as predictors of proficiency in English as a second language. Language Learning, 36(1), 27-45.

Chen, L.J. (1989). Some important characteristics of good language learners-A study of cadets from the Chinese Military Academy. A paper for the promotion of an associate professor. The Chinese Military Academy.

Cheng, H.Y., Lee, F.M., Liou, P.P., \& Chung, W.Y. ( 2010). Are females better language learners? WHAMPOA-An Interdisciplinary Journal, 59, 55-72. ISSN 1814-7704.

Christison M. A. (1996a). Teaching and learning languages through multiple intelligences. TESOL Journal 6 (1), 10-14.

Christison, M. A. (1998). An introduction to Multiple Intelligence Theory and second language learning. In J. M. Reid (Ed.), Understanding Learning Styles in the Second Language Classroom (pp. 1-14), 1998. New Jersey: Prentice Hall Regents.

Cohen, A. (2003). The learners' side of foreign language learning: Where do styles, strategies, and tasks meet? International Review of Applied Linguistics in Language Teaching, 41, 279-291.

College Entrance Examination (CEE). www.ceec.edu.tw/Ceeclntro/CeecEnglishProfile.htm

College Entrance Advanced Subject Test (CEAST). www.ceec.edu.tw/CeecIntro/CeecEnglishProfile.htm

Dornyei, Z. (1994). Motivation and motivating in the foreign language classroom. The Modern Language Journal, 78(3), 273-284.

Du, Z.M. (2006). Enlightenment of ambiguity tolerance and schema theory on college English listening teaching. Journal of the Chinese People's Armed Police Force Academy, 22(3), 43-45.

Ehrman, M. (1994). Weakest and strongest learners in intensive language training: a case study of extremes. In C.A. Klee (Ed.).Faces in a crowd: the individual learner in multisection courses. Boston: MA, Heinle \& Heinle.

Ehrman, M. (1999). Ego boundries and tolerance of ambiguity in second language learning. In J. Arnold (Ed.). Affect in language learning. Cambridge: Cambridge University Press.

Ehrlich, D. (1965). Intolerance of ambiguity. Walk's A scale: Historical comment. Psychological Reports, 17, 591-595. 
El-Koumy, A.S.A. (2000). Differences in EF reading comprehension among high-, middle-, and low-ambiguity tolerance students. Paper presented at the National Symposium on English Language Teaching in Egypt, March 21-23.

Ely, C. M. (1986). An analysis of discomfort, risk-taking, sociability, and motivation in the L2. Language Learning, 36(1), 1-25.

Ely, C. M. (1989). Tolerance of ambiguity and use of second language strategies. Foreign Language Annals, 22(5), 437-445.

Ely, C. M. (1995). Tolerance of ambiguity and the teaching of ESL. In J. M. Reid (Ed.): Learning styles in the ESL/EFL classroom (pp. 87-95). NY: Heinle \& Heinle Publishers.

Etzel, B. C. (1953). A study of the effects of frustration upon the preference for doing a subsequent task. Unpublished doctoral dissertation, State University of lowa.

Erten, I. \& Topkaya, E. (2009). Understanding tolerance of ambiguity of EFL learners in reading classes. At tertiary level. Novitas-Royal, 3(1), 29-44.

Frenkel-Brunswik, E. (1949). Intolerance of ambiguity as an educational and perceptual personality variable. Journal of Personality, 18, 108-43.

Fukuchi, N.T. \& Sakamoto, R. (2005). Affective dimensions of the Japanese foreign language learner: implications for psychological learner development in Japan. Journal of Multilingual and Multicultural Development, 26(4), 333-350.

Furnham, A. \& Marks, J. (2013). Tolerance of ambiguity: A review of the recent literature. Psychology, 4, 717-728.

Gardner, Howard. (1983). Frames of Mind: The Theory of Multiple Intelligences. NY: Basic Books.

Gardner, Howard. (1993). Multiple Intelligences: The Theory in Practice. New York: Basic Books.

Gardner, Howard. (1999). Intelligence Reframed. New York: Basic Books.

Gardner, Howard. (2000). The Disciplined Mind: beyond facts and Standardized Tests., The K-12 Education that Every Child Deserves. NY: Penguin Putnam.

Gardner, Howard. (2003). Multiple Intelligences After Twenty Years. Paper presented at the American Educational Research Association, Chicago, Illinois, April 21, 2003.

Gardner, Howard. (2004). Changing Minds: The Art and Science of Changing Our Own and Other People's Minds. Boston: Harvard Business School Press.

Gardner, Howard. (2005). Multiple Lenses on the Mind. Paper presented at the ExpoGestion Conference, Bogota Colombia, May 25, 2005.

Gardner, Howard. (2006). The Development and Education of the Mind: The Collected Works of Howard Gardner. London: Routledge.

Gardner, Howard. (2006). Multiple Intelligences: New Horizons. NY: Basic Books.

Gardner, Howard. (2007). Five Minds for the Future. Boston: Harvard Business School Press.

Gardner, Howard. (2008, April). The 25th anniversary of the publication of Howard Gardner's Frames of Mind: The Theory of Multiple Intelligence. Retrived from http://www.old-pz.gse.harvard.edu/PIs/Mlat25.pdf

Gay, L. R. \& Airasian, P. (2003). Educational Research: Competencies for Analysis and Applications (Seventh Edition). Merrill Prentice Hall, NJ.

Hanafiyeh Masoomeh. (2013). The relationship between Iranian EFL learners' Multiple Intelligence and success in foreign language learning. Asian Journal of Management Science and Education, 2(1), 97-105, January, 2013. 
Horwitz, E. (1988). The beliefs about language learning of beginning university students. The Modern Language Journal, 72, 182-193.

Horwitz, E. K., Horwitz, M. B. \& Cope, J. (1986). Foreign language classroom anxiety. The Modern Language Journal, 70, 125-132.

Jamieson, J. (1992). The cognitive styles of reflection/impulsivity and fields independence/ dependence and ESL success. The Modern Language Journal, 76(4), 491-501.

Kamran, S.K. (2011). Effects of gender on ambiguity tolerance of Iranian English language learners. Journal of Education and Practice, 2(11/12), 25-33.

Kazamina, V. (1999). How tolerant are Greek EFL learners of foreign language ambiguities. Leeds Working Papers in Linguistics, 7, 69-78."

Khajeh, A. (2002). The relationship between tolerance of ambiguity, gender, level of proficiency and use of second language learning strategies. Unpublished MA thesis. Tarbiat Modarres University, Iran.

Kissau, S. (2006). Gender differences in second language motivation: An investigation of micro-and macrolevel influences. Canadian Journal of Applied Linguistics, 9(2), 73-96.

Kondo-Brown, K. (2006). Affective variables and Japanese L2 reading ability. Reading in a Foreign Language, 18(1), 55-71.

Lado, R. (1965). Memory span as a factor in language learning. International Review of Applied Linguistics, 3, 123-129.

Lai, P. (2009). The necessity of studying learners' tolerance of ambiguity in foreign language education. Forum on Chinese Culture, 7, 287-289.

Lee, H.Y. (1998). Language learning strategies and tolerance of ambiguity of Korean midshipmen learning English as a foreign language. Unpublished doctoral dissertation. Ball State University, United States.

Levitt, E. E. (1953). Studies in intolerance of ambiguity: The decision location test with grade school children. Child Development, 24, 263-268.

Li, E.L. (2007). A study of non-English majors' differences in tolerance of ambiguity by gender and proficiency. Unpublished MA thesis. Jiangxi Normal University, China.

Li, M.Y.(2010). The impacts of ambiguity tolerance on reading comprehension of English majors. Journal of Hubei University of Economics (Humanities and Social Science), 7(4), 198-199.

Liu, C. (2015). Relevant researches on tolerance of ambiguity. Theory and Practice in Language Studies, 5(9), 1874-1882, September 2015.

Liu, F. (2006). Ambiguity tolerance in Chinese students of college English. Asian Social Science, 2(12), 96-99.

Liu, M. (2011). A survey on the relationship between tolerance of ambiguity and English reading comprehension performance of three-year English majors in college. Foreign Language Teaching and Research, 12, 116-117.

MacDonald, A. P. (1970). Revised scale for ambiguity tolerance: Reliability and validity. Psychological Reports, 25, 791-798.

Marzban, A. \& Barati, H., \& Moinzadeh, A. (2012). An investigation into Ambiguity tolerance in Iranian senior EFL undergraduates. English Language Teaching, 5(1), 76-85. January 2012.

Maubach, A.M. \& Morgan, C. (2001). The relationship between gender and learning styles amongst A level modern languages students. The Language Learning Journal, 23(1), 41-47.

McKenzie, Walter. (2004). Multiple Intelligencese and Instructional Technology. Retrived from http://surfaquarium.com. 
McLain, D. L. (1993). The MSTAT-1: A new measurement of an individual's tolerance for ambiguity. Educational and Psychological Measurement, 53, 183-189.

Myers, I. B., McCaulley, M. H. (1985). Manual: A guide to the development and use of the Myers-Briggs Type Indicator. Palo Alto, CA: Consulting Psychologists Press.

Naiman, N., Frohlich, M. \& Stern, H. H. (1975). The good language learner. The Ontario Institute for Studies in Education, 1975.

Norton, R. W. (1975). Measurement of ambiguity tolerance. Journal of Personality Assessment, 39, 607-619.

O'Connor, P. (1952). Ethnocentrism, intolerance of ambiguity and abstract reasoning ability. Journal of Abnormal and Social Psychology, 47, 526-530.

Oxford, R. L. (1989). Use of language learning strategies: A synthesis of studies with implications for strategy training. System, 17(2), 235-247.

Oxford, R. L. (1990). Language learning strategies: What every teacher should know. NY: Newbury House/Harper \& Tow.

Oxford, R. L. (1993). Instructional implications of gender differences in language learning styles and strategies. Applied Language Learning, 4, 65-94.

Oxford, R. L. (1995). Gender differences in language learning styles: What do they mean? In J. M. Reid (Ed.), Learning styles in the ESL/EFL classroom (pp. 34-46). Boston, MA: Heinle \& Heinle Publishers.

Oxford, R. L. (2003).Language learning styles and strategies: an overview. GALA, pp.1-25, 2003.

Pimsleur, P., Sundland, D. \& Mclntyre, R. (1966). Underachievement in foreign language learning. NY: MLA Materials Center.

Reid, J. M. (1984). Perceptual learning style preference questionnaire. In J. M. Reid (Ed.): Learning styles in the ESL/EFL classroom (pp. 202-204). NY: Heinle \& Heinle Publishers.

Reid, J. M. (1987). The learning style preference of ESL students. TESOL Quarterly, 21(1), 87-111.

Reid, J. M. (Ed.). (1995). Learning styles in the ESL/EFL classroom. Boston, MA: Heinle \& Heinle Publishers.

Reid, J. M. (1998). Understanding learning styles in the second language classroom. Upper Saddle River, NJ: Prentice Hall Regents.

Rostami, S. (2010). The relationship between emotional intelligence and EFL learners' language learning strategy use, unpublished M.A. thesis. Islamic Azad University of central at Tehran Branch, Tehran, Iran, 2010.

Saeedeh Karbalaee Kamran (2011). Effects of gender on ambiguity tolerance of Iranian English language learners. Journal of Education and Practice, 11\&12, 2011, 25-33.

Stake, R. E. (1988). Case study methods in educational research: Seeking sweet water. In R. M. Jaeger (Ed.): Complementary methods for research in education (pp.253-300). American Educational Research Association, Washington, DC.

Secondary Level English Proficiency Test. (1980). Test Form 1. Educational Testing Service. Princeton, NJ.

Shearer, Branton \& Fleetham, Mike (2008). Creating extra-ordinary teachers; Multiple intelligences in the classroom and beyond. The Continuum International Publishing Group

Smock, C. D. (1955). The influence of psychological stress on the intolerance of ambiguity. Journal of Abnormal and Social Psychology, 50, 177-182.

Stansfield, C. (1984). Reliability and validity of the Secondary Level English Proficiency Test. System, 12(1), $1-12$. 
Tirri, Kirsi and Nokelainen, Petri (2011). Measyring Multiple Intelligences and Moral Sensitives in Education. Sense Publishers, The Netherlands.

Wen, Q. F. (2003). The way to success for English study. Shanghai: Shang Foreign Language Education Press.

Witkin, H. A., Oltman, P. K., Raskin, E., \& Karp, S. A. (1971). Manual: Embedded Figures Test. Palo Alto, CA: Consulting Psychologists Press.

Wu, W. (2009). A study on ambiguity tolerance and reading anxiety of non-English majors university students. Foreign Language Teaching and Research, 29, 98-99.

$\mathrm{Xu}, \mathrm{Y}$. (2005). Chinese learners' tolerance of ambiguity in learning English as a foreign language. Journal of Zhejiang Education Institute, 1, 24-28.

$\mathrm{Yu}, \mathrm{Y}$. (2007), The influence of tolerance of ambiguity on learning strategies of listening comprehension. Unpublished M.A. thesis. Jilin University, China.

Zahra Jafari, Samira Yavari, Moein Shokri (2015). The impact of self-assessment of EFL learners' tolerance of ambiguity. International Journal of Language and Linguistics. 3(4), 2015, 271-274.

Zarashan, M. \& Ardeshiri, M. (2012). The relationship between emotional intelligence, language learning strategies and English proficiency among Iranian EFL university students. Journal of educational and instructional studies in the world, 2(3), 2012, 105-114. 